\title{
Metástasis cerebral de carcinoma urotelial piélico en riñón en herradura
}

\author{
J. M. Aranda Lassa, C. Ambroj Navarro, M. A. Trívez Boned, J. Lozano Enguita, \\ B. Blasco Beltrán
}

Sección de Urología. Hospital Ernest Lluch. Calatayud. Zaragoza.

Actas Urol Esp 2005; 29 (2): 238

$\mathrm{P}$ aciente de 74 años de edad remitido a consultas externas hospitalarias de este centro por hematuria macroscópica recidivante. En la exploración no se evidenciaron hallazgos patológicos. La realización de ecografia renal demuestra la existencia de riñón en herradura, itsmo central, malrotación riñón izquierdo con dilatación pielicalicial. TAC (Fig. 1): alteración morfológica renal (en herradura) el sístema colector izquierdo se encuentra dilatado, consiguiendose la eliminación de contraste en cortes realizados

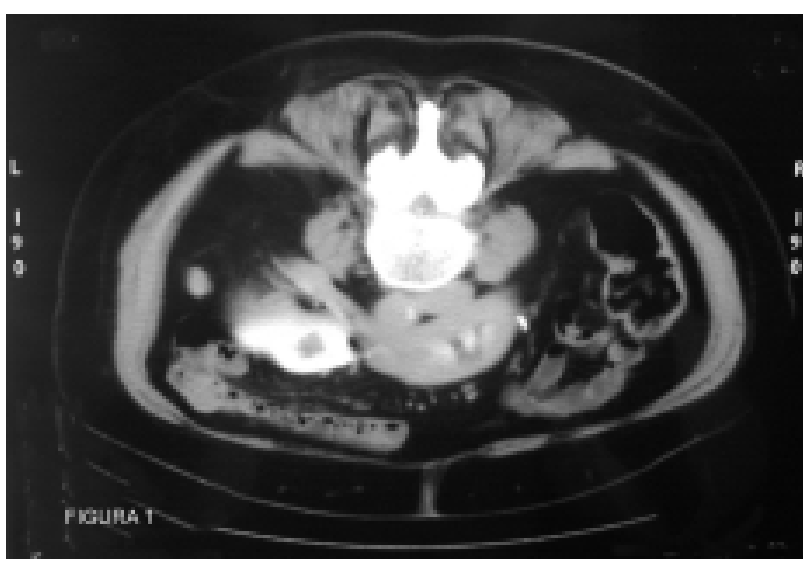

en decúbito prono, visualizandose una lesión de densidad sólida de $14 \mathrm{~mm}$. No se visualizan adenomegalias retroperitoneales. Se practicó Nefroureterectomía laparoscópica izquierda, presentando durante el postoperatorio cuadro de obnubilación, hemiparésia izquierda y que obligó a la realización de TAC cerebral (Fig. 2) poniendo de manifiesto la existencia de lesión sólida de 34 $\mathrm{mm}$ en lóbulo frontal derecho con edema y desplazamiento de estructuras cerebrales compatible con metástasis cerebral.

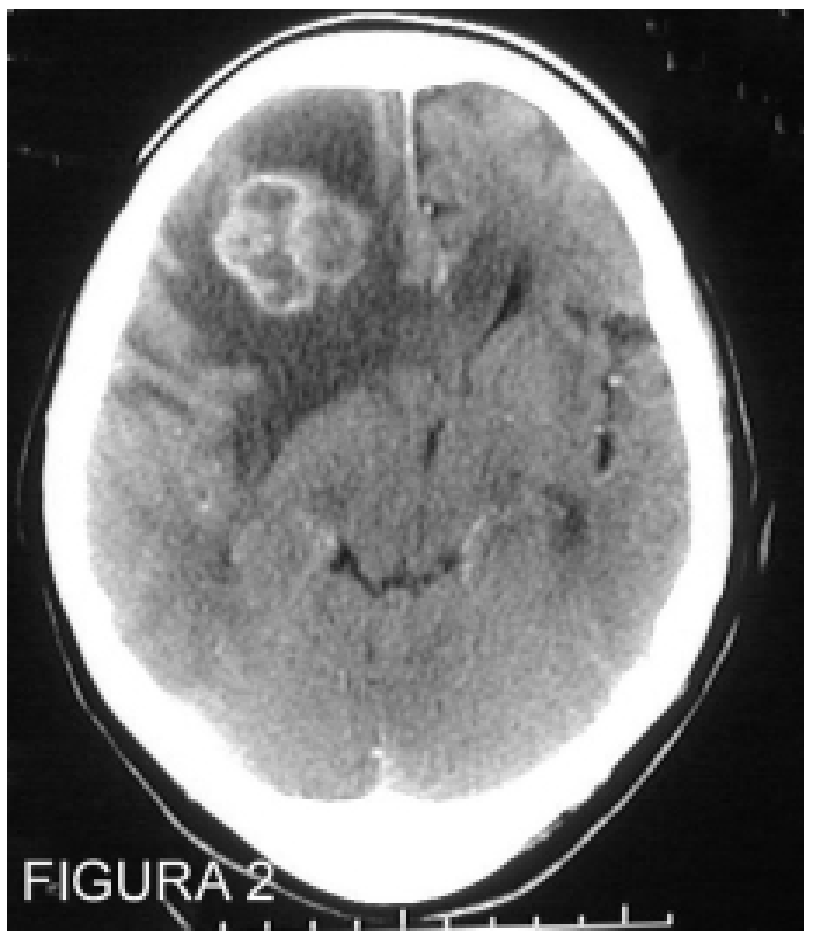

